\title{
THE PALM TREE COPERNICIA CERIFERA (CARNAÚBA) AS AN ECOTOPE OF RHODNIUS NASUTUS IN RURAL AREAS OF THE STATE OF PIAUÍ NORTHEASTERN BRAZIL
}

\author{
Artur da S. Pinto 1 and Dalva N. da C. Bento 2
}

\begin{abstract}
The C. cerifera palm tree (carnaúba) is widely distributed in the Northeastern Brazil, including the state of Piaui. This investigation revealed that $\mathrm{R}$. nasutus is the only triatomine species captured on that palm tree, in five different localities. $78 \%$ of palm trees were infested with triatomines, and $4.0 \%$ were infected with flagellates morphologically and biologically indistinguishable from Trypanosoma cruzi Birds, rodents and marsupials were found as major blood meal sources for $\mathbf{R}$. nasutus.
\end{abstract}

Key words: Triatomine. Rhodnius nasutus. Ecotope. Copernicia cerifera.

Palm trees of several species are described in South and Central America as ecotopes of triatomine vectors of $T$. cruzi, the aetiological agent of Chagas'

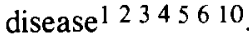

The paper describes the palm tree C. cerifera as the ecotope of $R$. nasutus in five different localities of the rural area of the State of Piaui.

\section{MATERIALS AND METHODS}

Capture of insects. In order to capture triatomines, palm trees were cut down over a white cloth. Each frond was removed from its base and carefully searched for the presence of triatomines. Any mammals were captured. The distribution of the five localities in the State of Piaui where palm trees were searched is shown in Figure 1.

Examination of triatomines. The triatomines were classified and examined for the presence of flagellates by abdominal compression or gut dissection. Groups of 3 mice (aproximately 2 months old) were inoculated intraperitoneally with flagellates collected from the triatomines. Mice were later examined by fresh blood preparations and xenodiagnosis in order to detect parasitaemia. The captured mammals were also examined for the presence of flagellates by the above two methods.

Blood meal source of triatomines. Evaluation of blood meal source by means of a precipitin test, using the gut content of triatomines, was performed at the Gorgas Laboratory (WHO-Panamá).

This work was supported by grants from Financiadora de Estudos e Projetos (FINEP).

1. Departamento de Microbiologia, ICB, Universidade Federal de Minas Gerais, Caixa Postal 2486 - 30000 Belo Horizonte, MG, Brazil.

2. Departamento de Biologia, CCN, Fundação Universidade Federal do Piaui, Teresina, PI, Brazil.

Recebido para publicação em $9 / 9 / 85$.

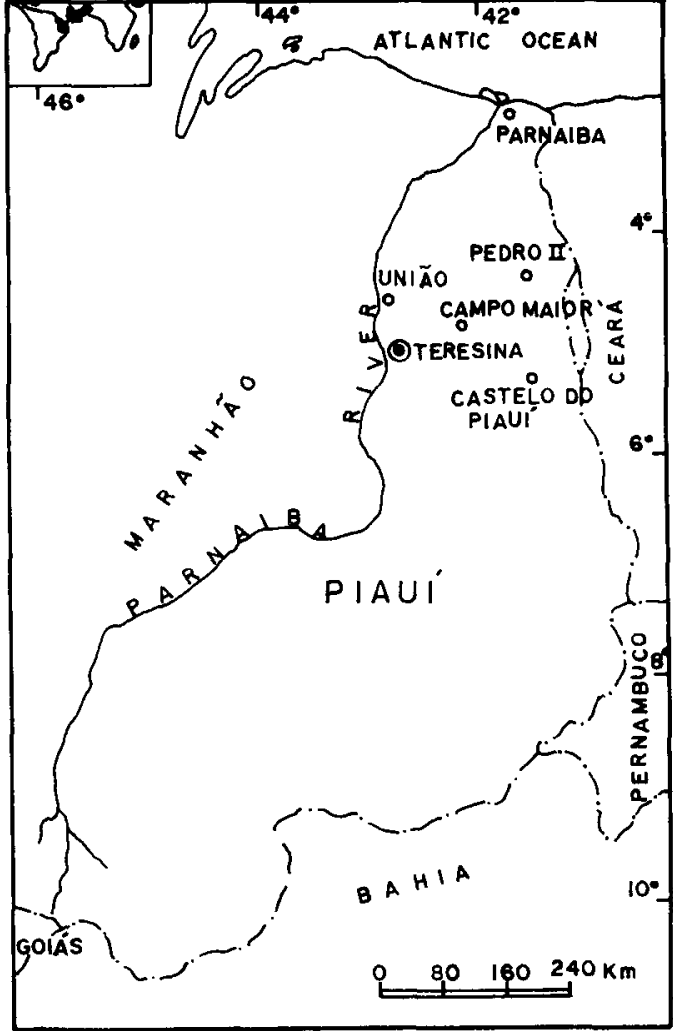

Figure 1-Map of the State of Piaui, showing the localities in the rural zone, where the palm trees $\mathrm{C}$. cerifera (carnaúba) were searched for the presence of triatomines. The State's capital (Teresina) is also indicated.

Xenodiagnosis. This technique, as used by Freitas ${ }^{9}$, consisted of feeding clean triatomines (3-4 instar), reared in the laboratory on vertebrate blood. It was performed using the species Triatoma brasiliensis, Rhodnius prolixus and Dipetalogaster maximus. About 10 insects were fed on each animal and 
their faeces submitted to microscopical examination 25 to 30 days after feeding.

\section{RESULTS}

Among 50 palm trees searched, 39 were infested by triatomines (78.0\%). A total of 234 triatomines were captured all being $R$. nasutus. The infection rate with $T$. cruzi was low (mean $4 \%$ ). Table
1 shows the data on the triatomines captured, and their infection index.

All groups of young mice inoculated with flagellates isolated from captured triatomines showed detectable parasitaemia. Of 78 precipitin tests performed, 76 were positive against different antisera, as showed in Table 2 . $R$. nasutus fed mainly on birds, rodents and marsupials.

Table 1 - Data on the Rhodnius nasutus captured on palm tree Copernicia cerifera (carnaúba) in five different localities, State of Piaui, Northeastern Brazil, and examined for T. cruzi.

\begin{tabular}{lrcccccccccc}
\hline \multirow{2}{*}{ Locality } & \multicolumn{3}{c}{ Adults } & \multicolumn{4}{c}{ Larvae } & \multicolumn{4}{c}{ Totals } \\
\cline { 2 - 13 } & \multicolumn{1}{c}{ Captured } & Examined & Infected & Captured & Examined & Infected & Captured & Examined & Infected & $\%$ \\
\hline União & 2 & 2 & 0 & 15 & 15 & 0 & 17 & 17 & 0 & 0.0 \\
Campo Maior & 10 & 10 & 2 & 28 & 28 & 0 & 38 & 38 & 2 & 5.0 \\
Castelo do Piaui & 20 & 20 & 0 & 20 & 20 & 0 & 40 & 40 & 0 & 0.0 \\
Pedro II & 5 & 5 & 1 & 52 & 52 & 0 & 57 & 57 & 1 & 2.0 \\
Parnaiba & 6 & 5 & 3 & 76 & 75 & 4 & 82 & 80 & 7 & 9.0 \\
\hline Total & 43 & 42 & 6 & 201 & 190 & 4 & 234 & 232 & 10 & 4.0 \\
\hline
\end{tabular}

Table 2 - Precipitin test for the identification of the blood meal source $\mathrm{R}$. nasutus captured on palm trees Copernicia ceriferia (carnauba) in five different localities, State of Piaui, Northeastern Brazil.

\begin{tabular}{|c|c|c|c|c|c|c|c|c|}
\hline \multirow[b]{2}{*}{ Locality } & \multicolumn{7}{|c|}{ Reactivity to precipitin test } & \multirow[b]{2}{*}{$\begin{array}{l}\text { Total } \\
\text { reactive }\end{array}$} \\
\hline & $\begin{array}{c}\text { Anti- } \\
\text { Bird }\end{array}$ & $\begin{array}{c}\text { Anti- } \\
\text { rodent } \\
\text { (Cricetidae) }\end{array}$ & $\begin{array}{c}\text { Anti- } \\
\text { marsupial } \\
\text { (Didelphidae) }\end{array}$ & $\begin{array}{c}\text { Anti- } \\
\text { amphibian }\end{array}$ & $\begin{array}{l}\text { Anti- } \\
\text { reptile }\end{array}$ & $\underset{\text { mammalian }}{\text { Anti- }}$ & $\begin{array}{l}\text { Anti- } \\
\text { bird and } \\
\text { reptile }\end{array}$ & \\
\hline União & 3 & - & - & - & - & - & - & 3 \\
\hline Campo Maior & 2 & 5 & - & 4 & 4 & 2 & 1 & 18 \\
\hline Castelo do Piauí & 13 & 6 & 8 & - & - & - & - & 27 \\
\hline Pedro II & 2 & 9 & 2 & - & 1 & 2 & 1 & 17 \\
\hline Parnaiba & 3 & 1 & - & 1 & - & - & 1 & 6 \\
\hline Total & 23 & 21 & 10 & 5 & 5 & 4 & 3 & 71 \\
\hline
\end{tabular}

An adult female of Marmosa agilis agilis and two Weidomys pyrhorrinus were captured on palm trees. None of them were found infected by flagellates.

\section{DISCUSSION}

The triatomine species $R$. nasutus found on the plam tree $C$. cerifera in the present survey were also predominant on the palm tree Orbignya martiana (babaçu) found in the urban zone of Teresina ${ }^{5}$. These palm species are widely distributed in this State. $R$. nasutus is reported as capable of colonizing natural and artificial ecotopes, and seems to be restricted to the Northeastern Brazil 7811.

The high index of palm tree infestation, the predominance of young instars, and the data on the blood meal source of $R$. nasutus presented here, agrees with our previous findings ${ }^{5}$. Contrary to the previous report, lower numbers of triatomine per palm and a lower infection index of the triatomine by flagellates, were found. $C$. cerifera is preserved in the rural area of the State of Piaui (from it's leaves carnauba wax is extracted) and this may have led to the maintenance of a relative ecological equilibrium. 
We believe that the flagellates found in the $R$. nasutus in the present study are $T$. cruzi, mainly by their capacity to produce parasitaemia in young mice, and because flagellates with similar characteristics were found in this triatomine species in the urban zone of Teresina ${ }^{5}$.

Chagas' disease remains a serious public health problem in Brazil. In many regions the $T$. cruz $i$ sylvatic cycle may have importance in maintaining the domestic cycle. Thus, the characteristics of the sylvatic cycle in each region may be important in future campaigns to control the disease.

\section{SUMÁRIO}

A palmeira C. cerifera (carnaúba) é largamente distribuida no Nordeste do Brasil onde está situado o Estado do Piauí. Esta investigação revelou que R. nasutus foi a única espécie de triatomíneo capturada neste tipo de palmeira, na área rural deste Estado, em cinco localidades diferentes. Setenta e oito por cento das palmeiras estavam infestadas com triatomineos, dos quais $4,0 \%$ estavam infectados com flagelados morfologicamente e biologicamente indistingüiveis do T. cruzi. Aves, roedores e marsupiais foram identificados como as principais fontes alimentares para o $\mathbf{R}$. nasutus.

Palavras chaves: Triatomineo. Rhodnius nasutus. Ecótopo. Copernicia cerifera.

\section{ACKNOWLEDGEMENTS}

We thank Dr. J. C. Pinto Dias for suggestions, the Gorgas Laboratory (WHO-Panamá) for performing the precipitin tests and Dr. A.R. Bogliolo for revision of the text.

\section{REFERENCES}

1. Alencar EJ , Bezerra OF. Estudo sobre a epidemiologia da doença de Chagas no Ceará. XXIV. Ecologia de triatomineos no municipio de Crato. Triatomineos de palmeiras. In: Resumos do V Congresso Brasileiro de Parasitologia, Rio de Janeiro, p. 29, 1980.

2. Barreto MP, Carvalho JR. Estudos sobre reservatórios e vetores silvestres do Trypanosoma cruzi. XII. Inquérito preliminar sobre triatomineos silvestres no municipio de Uberaba, Minas Gerais. Revista Brasileira de Biologia 26:5-14, 1966.

3. Barreto MP, Albuquerque RDR, Funayama GK. Estudos sobre reservatórios e vetores silvestres do Trypanosoma cruzi. XXXVI. Investigações sobre triatomineos de palmeiras no municipio de Uberaba, MG, Brasil. Revista Brasileira de Biologia 29:577-589, 1969.

4. Barreto MP, Ribeiro RD, Rocha GM. Estudo sobre reservatórios e vetores silvestres do Trypanosoma cruzi. LXIX. Inquerito preliminar sobre triatomineos silvestres na Região do Triângulo Mineiro, MG. Brasil. Revista Brasileira de Biologia 38:633-637, 1978.

5. Bento DNC, Branco AZCL, Freitas MR, Pinto, AS. Epidemiologic studies of Chagas' disease in the urban zone of Teresina. State of Piaui, Northeastern Brazil. Revista da Sociedade Brasileira de Medicina Tropical 17:199-203, 1984.

6. Diotaiuti L, Silveira AC, Elias M. Sobre o encontro de Rhodnius prolixus Stal 1858, em macaubeiras. Revista Brasileira de Malariologia e Doenças Tropicais 36:1114, 1984.

7. Forattini OP. Biogeografia, origem e distribuição de triatomíneos no Brasil. Revista da Saúde Pública 14:265-299, 1980.

8. Forattini OP, Barata JMS, Santos JLF, Silveira AC. Hábitos alimentares, infecção natural e distribuição de triatomíneos na Região Nordeste do Brasil. Revista de Saúde Pública 15: 113-164, 1981.

9. Freitas JLP. Observações sobre xenodiagnóstico praticado em reservatórios domésticos e silvestres do Trypanosoma cruzi em localidade endêmica da moléstia de Chagas. O Hospital 38:521-529, 1950.

10. Gamboa Cuadrado J. Comprobación de Rhodnius prolixus extradomiciliario en Venezuela. Boletin de la Oficina Sanitaria Panamericana 1:18-25, 1963.

11. Lent H, Jurberg J. O gênero Rhodnius Stal, 1859, com um estudo sobre a genitália das espécies (Hemiptera, Reduviidae, Triatominae). Revista Brasileira de Biologia 29:487-560, 1969. 